\title{
Volume regulation of muscle cells in the carp Cyprinus carpio in response to hypernatremia
}

\author{
Martemyanov $\mathrm{VI}^{1}$, Poddubnaya $\mathrm{NY}^{2}$ \\ Papanin Institute for Biology of Inland Waters, Russian Academy of Sciences, Borok, Yaroslavl oblast, Russia. \\ martem@ibiw.yaroslavl.ru
}

\begin{abstract}
BACKGROUND: Hypernatremia supports the movement of water from the intracellular to the intercellular space. This shift leads to cells shrinkage and disruption of intracellular processes, representing risk factors of morbidity and mortality in clinical circumstances. On the other hand, hypernatremia triggers protective mechanisms that counteract damage of cells.

OBJECTIVES: To determine in experiments in vivo the ranges of sodium content regulation in the blood plasma of carp characterizing the norm and hypernatremia. To identify the patterns volume regulation of skeletal muscles cells in response to hypernatremia.

METHODS: Carps were acclimating for 3 weeks to a different salinity in the range of $0-12 \mathrm{~g} / \mathrm{L}$. In the plasma and muscle tissue the concentration of sodium, potassium, calcium and magnesium was determined by the method of flame spectrophotometry. Water content in the muscles has been additionally determined.

RESULTS: Carps acclimated in the salinity range of 0-6 g/L, maintained the concentration of sodium in blood plasma within of the range of $129-135 \mathrm{mmol} / \mathrm{L}$ (normonatremia). In the salinity zone of $6-12 \mathrm{~g} / \mathrm{L}$ concentration of sodium in the blood plasma of fish has increased to $207 \mathrm{mmol} / \mathrm{L}$ (hypernatremia). Hypernatremia was causing the increase of the sodium, potassium, calcium and magnesium content in carp muscles and the drop of water level. CONCLUSIONS: Muscle tissue of carp adapts to hypernatremia by means of increasing inorganic ions by 70.8 $\%$ and organic osmolytes by $29.2 \%$ (Fig. 2, Ref. 51). Text in PDF www.elis.sk.

KEY WORDS: blood plasma, muscle tissue, hypernatremia, volume regulation of muscle cells.
\end{abstract}

\section{Introduction}

Normally, the level of sodium in human blood plasma is maintained in the narrow range of concentrations $(1,2)$. Higher concentrations of sodium in the blood plasma reveal elderly people and children with symptoms of diarrhea (3-5). Hypernatremia is often revealed by the patients of intensive therapy departments creating the risk for mortality $(1,6-8)$. Hypernatremia leads to an increase of the internal environment osmolality (9) causing a drop in osmotic pressure between the extracellular and intracellular body fluid. Cells of various organs and tissues of the body must have adaptive mechanisms to this situation. Since taking of human tissue samples is prohibitive, adapting mechanisms of the body cells to hypernatremia are studied on animals, usually in vitro.

Adaptation mechanisms of the erythrocytes of carp Cyprinus carpio and the river flounder Platichthys flesus to hypernatremia

${ }^{1}$ Papanin Institute for Biology of Inland Waters, Russian Academy of Sciences, Borok, Yaroslavl oblast, Russia, and ${ }^{2}$ Cherepovets State University, Cherepovets, Vologda oblast, Russia

Address for correspondence: V.I. Martemyanov, Papanin Institute for Biology of Inland Waters, Russian Academy of Sciences, 152742 Borok, Yaroslavl oblast, Russia,

Acknowledgements: This research was performed in the framework of the state assignment: theme No. AAAA-A18-118012690101-2, supported in part by RFBR (project No. 16-04-00120-a). in experiments in vitro and in vivo differ significantly (10). This shows that for adequate understanding of the processes that occur when different types of body cells are adapting to the increase of sodium concentration in the extracellular fluid, data obtained in vivo is required. It is especially important to take this into account in clinical examinations and developing of treatment methods from hypernatremia consequences for humans.

It is determined that in freshwater hydrobionts in the zone of critical salinity (10-15), and in euryhaline species during transition from freshwater to seawater (16-20) the level of sodium and chloride ions in the blood plasma increases. This situation is an ideal model for studying adaptation mechanisms of various organs and tissues of organisms to increasing sodium concentration of extracellular fluid in vivo.

Work objective - to determine in experiments in vivo the ranges of sodium regulation in the blood plasma of carp which characterize the norm (normonatremia) and hypernatremia. To identify the patterns volume regulation of skeletal muscles cells in response to hypernatremia.

\section{Materials and methods}

The experiments were performed with carps of the age $1^{+}$ in winter period at water temperature of $13-14{ }^{\circ} \mathrm{C}$. The groups of six specimens were placed in $300-\mathrm{L}$ aquaria filled with artesian water (contents of sodium, potassium, calcium, and magne- 

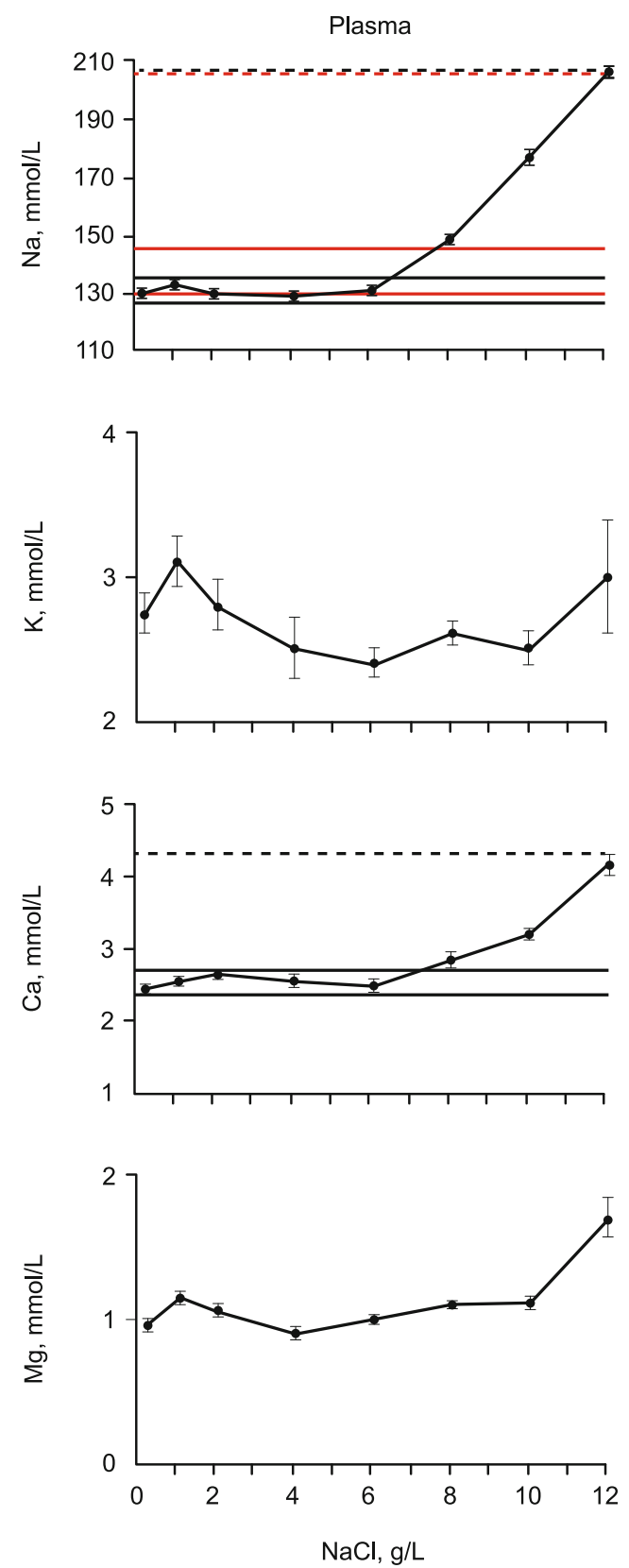
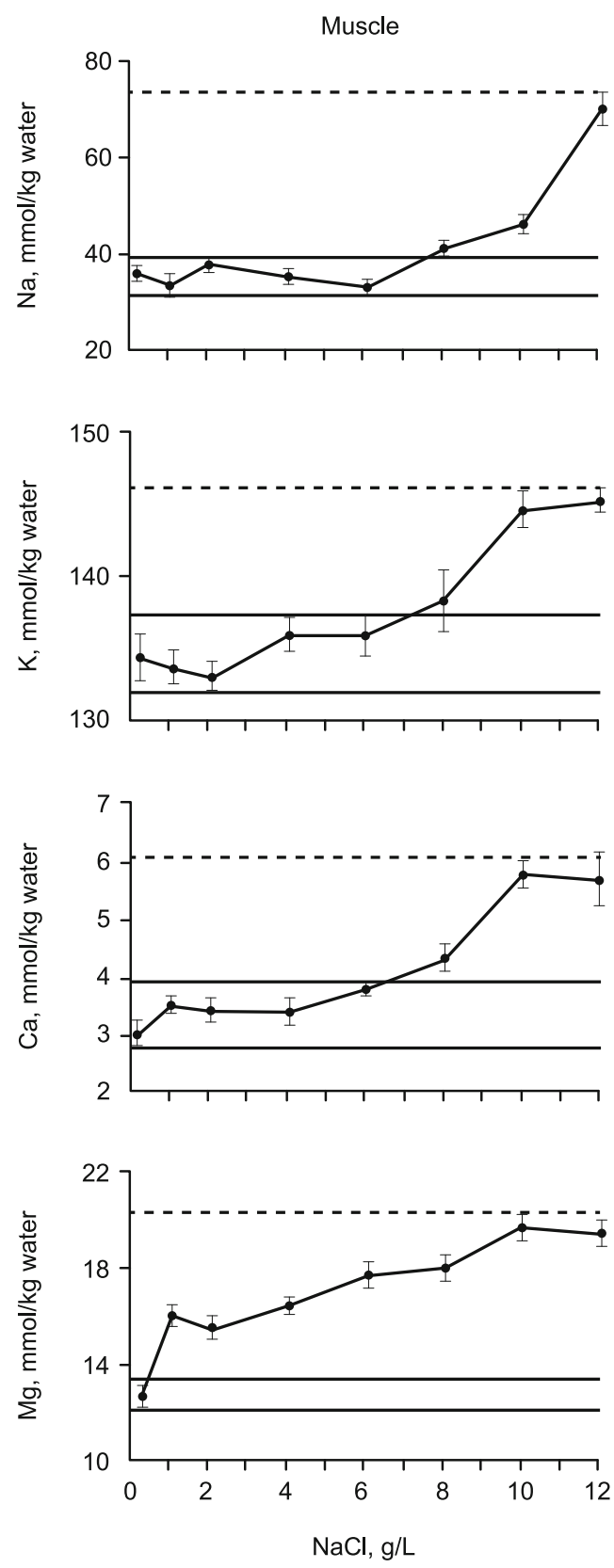

Fig. 1. Regulatory ranges of sodium, potassium, calcium, magnesium in the blood plasma and carp muscle tissue are at norm (borders are marked with solid black lines) and at hypernatremia (the upper limits are indicated by dashed lines of black color). Red solid lines show the boundaries of normonatremia, and the dashed line shows the border limit of hypernatremia in the human blood plasma.

sium were $0.46,0.04,2.00$, and $0.48 \mathrm{mM} / \mathrm{L}$, respectively). In one aquarium, the fish specimens were kept in artesian water; in the other seven $\mathrm{NaCl}$ of $0.5 \mathrm{~g} / \mathrm{L}$ was added daily. When $\mathrm{NaCl}$ concentrations reached $1,2,4,6,8,10$, and $12 \mathrm{~g} / \mathrm{L}$ respectively, salting was stopped and the fish specimens were maintained in the given constant conditions for not less than 3 weeks. Following this acclimation period, the fish were quickly caught and the blood was sampled from the caudal artery using a Pasteur pipette. Muscle tissue was sampled in the zone of the 2 nd -4 th ribs. The subse- quent procedures of blood and muscle sampling were performed as described previously (21).

Concentration of sodium and potassium in the samples was measured using propane by a Flapho-4 spectrophotometer; concentration of calcium and magnesium was measured in an air-acetylene flame in absorption regime by an AAS-1 atomic absorption photometer (CarlZeiss, Iena, Germany). Ion concentration in the plasma is defined in $\mathrm{mmol} / \mathrm{L}$, in the muscle - in $\mathrm{mmol} / \mathrm{kg}$ of water. Water content in the muscle is defined in percentage. 


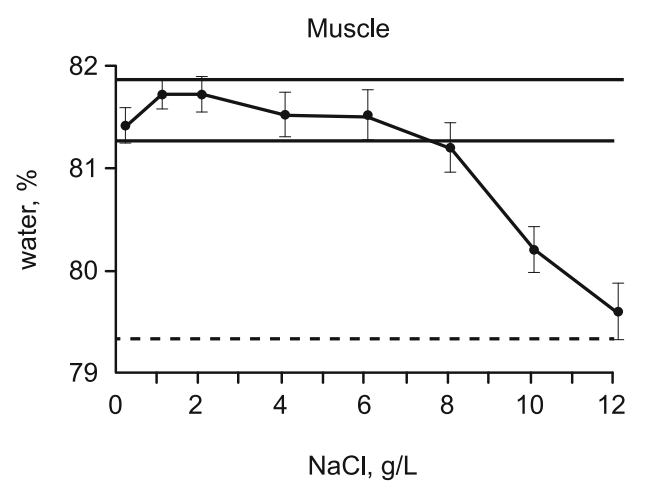

Fig. 2. The range of the water level regulation in carp muscles at norm (the borders are separated by solid lines) and at hypernatremia (the border is marked with a dashed line).

Average results and their standard deviations have been presented. Accuracy of the differences was evaluated with the help of Student coefficient with confidence probability of $\mathrm{p} \leq 0.05$. Relationship between the environment salinity and the studied parameters have been evaluated based on the Spearman rank correlation coefficient $\left(\mathrm{r}_{\mathrm{s}}\right)$; for sampling less than 5 - based on the accuracy approximation coefficient $\left(\mathrm{R}^{2}\right)$.

\section{Results}

Carps acclimated in the salinity range of $0-6 \mathrm{~g} / \mathrm{L}$ maintained the concentration of sodium in the blood plasma within the range of $129-135 \mathrm{mmol} / \mathrm{L}$ (normonatremia), and in the muscle tissue 32-39 mmol/kg water (Fig. 1, the range boundaries are highlighted by solid black lines). In the salinity zone of 6-12 g/L, sodium concentration in blood plasma of fish has increased exponentially $\left(\mathrm{R}^{2}=0.996\right)$ to $207 \mathrm{mmol} / \mathrm{L}$, and in the muscle tissue to 73 $\mathrm{mmol} / \mathrm{kg}$ water (the upper boundaries of the ranges are indicated by dashed lines).

Concentration of potassium in the blood plasma of carps did not depend on the environmental salinity $\left(r_{s}=-0.065\right)$. Carps acclimated in the salinity range of $0-6 \mathrm{~g} / \mathrm{L}$ maintained the potassium concentration in the range of $132-137 \mathrm{mmol} / \mathrm{kg}$ water (Fig. 1, the range boundaries are highlighted by solid lines) in the muscle tissue, and in the salinity zone of 6-10 g/L increased to $146 \mathrm{mmol} /$ $\mathrm{kg}$ of water. In the salinity zone of $10-12 \mathrm{~g} / \mathrm{L}$, the level of potassium in the muscle of carps did not change.

In carps acclimated in the range of $0-6 \mathrm{~g} / \mathrm{L}$, the calcium content in the blood plasma did not depend on the salinity of the medium, being maintained in the range of $2.4-2.7 \mathrm{mmol} / \mathrm{L}$ (the boundaries are marked by solid lines), and in the salinity zone of $6-12 \mathrm{~g} / \mathrm{L}$ has significantly increased $\left(\mathrm{R}^{2}=0.961\right)$ to $4.3 \mathrm{mmol} / \mathrm{L}$ (marked with a dashed line). Carps acclimated in the salinity range of $0-6$ $\mathrm{g} / \mathrm{L}$, maintained calcium concentration in the muscle tissue in the range of 2.8-3.9 mmol $/ \mathrm{kg}$ water (Fig. 1, solid lines), and in the salinity zone of $6-10 \mathrm{~g} / \mathrm{L}$ increased to $6.1 \mathrm{mmol} / \mathrm{kg}$ water (indicated by a dashed line). In the salinity zone of $10-12 \mathrm{~g} / \mathrm{L}$, the level of calcium in carp muscle did not change.
Carps acclimated in the range of $0-10 \mathrm{~g} / \mathrm{L}$ maintained magnesium concentration in the blood plasma within $0.9-1.1 \mathrm{mmol} / \mathrm{L}$, and in the critical salinity of $12 \mathrm{~g} / \mathrm{L}$ sharply increased to 1.8 $\mathrm{mmol} / \mathrm{L}$. Carps acclimated in fresh water regulated concentration of magnesium in the muscles in the range of $12.1-13.3 \mathrm{mmol} / \mathrm{kg}$ water (Fig. 1, marked with solid lines), and in the salinity zone $1-10 \mathrm{~g} / \mathrm{L}$ increased to $20.2 \mathrm{mmol} / \mathrm{kg}$ water (marked with a dashed line). In the salinity zone of 10-12 g/L the level of magnesium in the muscle of carps did not change.

In the range of $0-6 \mathrm{~g} / \mathrm{L}$ the water content in carp muscle did not depend on the salinity of the environment, maintaining within $81.2-81.9 \%$, and in the salinity zone $6-12 \mathrm{~g} / \mathrm{L}$ significantly decreased to $79.3 \%$ (Fig. 2).

\section{Discussion}

Concentration of sodium in the blood plasma of carp is maintained normally within a certain narrow range (normonatremia) (Fig. 1, the boundaries are separated by solid lines of black color), and when hypernatremia rises to the maximum limit value (indicated by a dashed line of black color).

According to different authors, in humans the value of the lower limit of normonatremia rather differs, reported values are $130 \mathrm{mmol} / \mathrm{L}(22,23), 134 \mathrm{mmol} / \mathrm{L}(24), 135 \mathrm{mmol} / \mathrm{L}(1,2)$. The threshold value dividing the upper limit of normonatremia and the lower limit of hypernatremia is $145 \mathrm{mmol} / \mathrm{L}(1,2)$. Summarizing the available results, it should be acknowledged that concentration of sodium in the blood plasma of healthy people (range of normonatremia) is commonly maintained in the range of 130-145 $\mathrm{mmol} / \mathrm{L}$ (Fig. 1, the boundaries are marked with red solid lines). In the state of hypernatremia, concentration of sodium in human blood plasma can be increased up to $206 \mathrm{mmol} / \mathrm{L}$ (25, Fig. 1, red dashed line). The comparison shows that the range of sodium content in the internal environment, compatible with the vital activity of cells in various organs and tissues of carp and human, is similar. It can be expected that the adaptation mechanisms of various types of body cells to an increase of sodium concentration in the internal environment of carp and humans will act in a similar way.

The osmotic concentration of blood plasma and muscle tissue of the body are in equilibrium (21). In the state of hypernatremia, the content of ions in the blood plasma of carp increased: sodium by $72 \mathrm{mmol} / \mathrm{L}$, and calcium by $1.6 \mathrm{mmol} / \mathrm{L}$, in total amounting to $73.6 \mathrm{mmol} / \mathrm{L}$. In muscles, the sodium concentration increased by $34 \mathrm{mmol} / \mathrm{kg}$ water, potassium by $9 \mathrm{mmol} / \mathrm{kg}$ water, calcium by $2.2 \mathrm{mmol} / \mathrm{kg}$ water, magnesium by $6.9 \mathrm{mmol} / \mathrm{kg}$ water, in total amounting to $52.1 \mathrm{mmol} / \mathrm{kg}$ water. Difference of the total ion concentration between the plasma and muscle tissue is $21.5 \mathrm{mmol}$. This deficiency of ions in carp muscle tissue was compensated by accumulation of organic osmolytes. Maintenance of the structure and function of macromolecules, including proteins, compatible with vital activity of the cell can be achieved only in narrow ranges of intracellular concentration of inorganic ions (26). Intracellular accumulation of electrolytes is limited because high ion concentrations interfere with structure and function of macromolecules, including proteins $(27,28)$. 
Reaching maximum value of potassium, calcium, magnesium in carp muscles (Fig. 1, dashed lines, specific values are presented in the results) was observed at salinity of $10 \mathrm{~g} / \mathrm{L}$. Carps acclimated in the salinity zone of 10-12 $\mathrm{g} / \mathrm{L}$ did not increase the level of these ions in muscles, thus preventing their damaging effects on intracellular processes.

In addition to the ionic mechanisms, volume regulation cells specifically accumulate organic osmolytes to increase intracellular osmolality (26-30). Organic osmolytes need to be non-perturbing solutes that do not interfere with protein function even when occurring at high intracellular concentrations $(28,29,31,32)$.

Increase of glycine, histidine and alanine concentration in the muscle of carp has been observed in the zone of critical salinity (33). Compensation of intracellular osmotic concentration in muscles of toads due to organic substances in state of increase salinity has comprised from $53 \%$ of Bufo viridis and $57 \%$ of Bufo boreas (34). Adaptation of Tilapia mossambica to hyperosmotic conditions was accompanied by the cleavage of proteins and accumulation of amino acids in muscles (35). When euryhaline teleosts go from the fresh water to the sea water, there is an $82 \%$ increase in the amino-acid content of the thick-lipped mullet Crenimugil labrosus muscle and a $66 \%$ increase in that of the flounder Paralichthys lethosligma muscle (36). In the experiments in vivo (37) and in vitro (20) cell volume regulation in heart ventricles of the euryhaline flounder Platichthys flesus is carried out under hyperosmotic conditions by means of increased intracellular concentration of potassium and taurine.

Thus, in the zone of critical salinity increase of osmotic concentration of the freshwater hydrobionts internal environment has been observed, mainly due to the increase of sodium and chloride ions. Carp muscle tissue adapts to the increase of extracellular fluid osmotic concentration due to accumulation of inorganic ions (mainly sodium, potassium and magnesium) and organic osmolytes. Despite these adaptations, recovery of initial volume of muscle cells has not been achieved. This is demonstrated by decrease of the water level in carp muscles acclimated in the critical salinity zone (Fig. 2). Decreased intracellular fluid volumes of the carps in the critical salinity zone were determined using carboxyl-14C-inulin (12).

When cultivating freshwater ciliate Tetrahymena pyriformis in solutions with sodium content of 36.5 and $223 \mathrm{mmol} / \mathrm{L}$, average cell volume has decreased from $16-18.3 \mu \mu \mathrm{l}$ to $9.5 \pm 0.47 \mu \mu \mathrm{l}$. At the same time, water level in the cells has decreased from $80.7 \%$ to $71.2 \%$ (38). In the zone of critical salinity of $12-14 \mathrm{~g} / \mathrm{L}$ fingerling of grass carp Ctenopharyngodon idella has decreased the total body weight by $8.5-11.3 \%$; water content in the muscle tissue has decreased from $80 \%$ in fresh water to $74.4 \%$ at $14 \mathrm{~g} / \mathrm{L}$ (39). Within the tolerant salinity range, the total body water content of carp and tubenose goby is supported at stable level, demonstrating standard physiological functioning of the osmotic regulation. Hypohydremia is observed when the organism is exposed to water of critical salinity, indicating problems with osmotic regulation (14). Decrease of water level in the muscles of two toad species acclimated to hyperosmotic salinity has been observed (34). Hypernatremic dehydration was observed in infants (40) and elderly people (41).
At transition of different species of euryhaline fish from freshwater to the marine environment increase of extracellular fluid osmolality occurs due to increase of sodium and chloride ions (16-20). During transfer of killifish Fundulus heteroclitus from freshwater to seawater the plasma osmolality increased, muscle cell shrinkage occurred. During prolonged acclimation cell water content returns to a higher value (17). Water content of the muscles did not change at adaptation of Tilapia mossambica to hyperosmotic conditions (18). Constancy of the water content in the muscles reflects ability of the cells to regulate volume. In the experiments in vivo (37) and in vitro (20) cell volume regulation in heart ventricles of the euryhaline flounder Platichthys flesus is carried out under hyperosmotic conditions. The water content of the heart ventricle cells remained constant.

Thus, the muscle tissue of freshwater organisms adapts to hypernatremia due to accumulation of inorganic ions (mainly sodium, potassium and magnesium) and organic osmolytes. Despite these adaptations, the restoration of the original volume of muscle cells, definitive normonatremia, is not achieved. Hypernatremic dehydration in humans indicates a pattern of regulation of cell volume similar to that of freshwater organisms. In euryhaline species in the transition from fresh water to sea water, the water content in the muscles does not change, indicating the restoration of the volume of muscle cells to the original level.

Mechanisms involved in volume regulation of cell in response to hyperosmotic solutions have been studied in in vitro experiments. It was shown that hyperosmotic solutions cause volume reduction of different cell types in the initial period due to the exit of water by osmotic gradient $(20,42-48)$. Movement of water causes activation of several ion transporters in cell membranes. Activation of the $\mathrm{Na}^{+}-\mathrm{K}^{+}-2 \mathrm{Cl}^{-}$cotransporter leads to the intracellular transfer of sodium chloride and potassium chloride. Activation of $\mathrm{Na}^{+} / \mathrm{H}^{+}$exchange and $\mathrm{Cl}^{-} / \mathrm{HCO}_{3}^{-}$exchange leads also to sodium chloride entry into the cells. Sodium ion entering the cells is extruded through $\mathrm{Na}^{+} / \mathrm{K}^{+}$-ATPase in exchange for potassium (27, $29,49-51)$. The overall balance of these processes is an increase of cell potassium and chloride compensating for the increase of extracellular osmolality.

In experiments in vivo the carp muscle tissue has adapted to hypernatremia by accumulation of not only potassium, but also sodium and magnesium (Fig. 1). Muscular cells of two species of toads (34) and of crucian carp (21) adapted to hypernatremia by means of accumulation of sodium and potassium ions.

The results show that the pattern of the cell volume regulation in response to hypernatremia in experiments in vitro and in vivo is different. This is important to take into account in clinical studies. Changes in cellular inorganic ion levels can alter resting membrane potential, the rates of enzymatically catalyzed reactions and membrane solute transport that is coupled to ion gradients. Different patterns of cell volume regulation, realized in vitro and in vivo, will affect the intracellular processes in different ways. Consequently, the cell volume regulation pattern realized in vivo will be adequate for the organism. Since the pattern of the muscle tissue cell volume regulation, realized in vivo in response to hypernatremia, functions in different vertebrate species (carp, crucian 
carp, two species of toads) in a similar way, a similar reaction of humans should be expected.

\section{Conclusion}

The method of acclimating freshwater hydrobionts to the salinity of environment within total interval compatible with the vital activity of organisms of different species allows to determine the ranges of normontreemia and hypernatremia regulation. To identify patterns and limits of changes in various inorganic ions and organic osmolytes involved in volume regulation of various types of body cells in response to hypernatremia. To assess the effect of inorganic ions on intracellular processes. The muscle tissue of carp adapts to hypernatremia by means of accumulation of inorganic ions (mainly sodium, potassium and magnesium) and organic osmolytes. Despite these adaptations, restoration of the original volume of muscle cells, characteristic for normonatremia, is not achieved. Hypernatremic dehydration is observed in the human body and freshwater fish. The range of sodium content in the internal environment, compatible with the vital activity of the cells of various organs and tissues of the body of carp and human, is similar. It can be expected that the mechanisms of muscle cells adaptation to an increase in the sodium concentration in the internal environment of a human body will be carried out in the same way as in the body of carp.

\section{References}

1. Mendes RS, Soares M, Valente $\mathbf{C}$ et al. Predialysis hypernatremia is a prognostic marker in acute kidney injury in need of renal replacement therapy. J Crit Care 2015; 30: 982-987.

2. Han SS, Bae E, Kim DK et al. Dysnatremia, its correction, and mortality in patients undergoing continuous renal replacement therapy: a prospective observational study. BMC Nephrology 2016. doi: org/10.1186/ s12882-015-0215-1.

3. Snyder NA, Feigal DW, Arieff AI. Hypernatremia in elderly patients. A heterogeneous, morbid, and iatrogenic entity. Ann Intern Med 1987; 107: 309-319.

4. Adrogue HJ, Madias NE. Hypernatremia. N Engl J Med 2000; 342: 1493-1499.

5. Hawkins RC. Age and gender as risk factors for hyponatremia and hypernatremia. Clin Chim Acta 2003; 337: 169-172.

6. Aiyagari V, Deibert E, Diringer MN. Hypernatremia in the neurologic intensive care unit: how high is too high? J Crit Care 2006; 21: 163-172.

7. Lindner G, Funk GC, Schwarz C et al. Hypernatremia in the critically ill is an independent risk factor for mortality. Am J Kidney Dis 2007; 50: 952-957.

8. Funk GC, Lindner G, Druml W et al. Incidence and prognosis of dysnatremias present on ICU admission. Intensive Care Med 2010; 36 : 304-311.

9. Kumar S, Berl T. Sodium. Lancet 1998; 352: 220-228.

10. Martemyanov VI. Mechanisms of regulation of erythrocyte volume in common carp Cyprinus carpio (Cyprinidae) at increase in the osmotic concentration of blood plasma within the zone of critical water salinity. $\mathrm{J}$ Ichthyol 2017; 57: 306-312.
11. Davis KB, Simco BA. Salinity effects on plasma electrolytes of channel catfish, Ictalurus punctatus. J Fish Res Board Can 1976; 33: 741-746.

12. Hegab SA, Hanke W. Electrolyte changes and volume regulatory processes in the carp (Cyprinus carpio) during osmotic stress. Comp Biochem Physiol 1982; 71A: 157-164.

13. Martemyanov VI. Influence of environmental mineral composition on the indices of water - salt metabolism in Dreissena polymorpha Pallas introduced in the Rybinsk reservoir. Rus J Biol Invasions 2011; 2: 213-222.

14. Martemyanov VI, Borisovskaya EV. Indices of salt and water metabolism in tubenose goby Proterorhinus marmoratus Pallas, introduced into Rybinsk reservoir, and in indigenous carp Cyprinus carpio L. depending on environmental salinity. Rus J Biol Invasions 2012; 3: 110-117.

15. Christensen EAF, Svendsen MBS, Steffensen JF. Plasma osmolality and oxygen consumption of perch Perca fluviatilis in response to different salinities and temperatures. J Fish Biol 2016. doi: 10.1111/jfb.13200, available online at wileyonlinelibrary.com.

16. Fugelli K, Zachariassen KE. The distribution of taurine, gammaaminobutyric acid and inorganic ions between plasma and erythrocytes in flounder (Platichthys flesus) at different plasma osmolalities. Comp Biochem Physiol 1976; 55A: 173-177.

17. Schmidt-Nielsen B. Volume regulation of muscle fibres in the killifish, Fundulus heteroclitus. J Exp Zool 1977; 199: 411-418.

18. Assem H, Hanke W. Volume regulation of muscle cells in the euryhaline teleost, Tilapia mossambica. Comp. Biochem. Physiol. 1979; 64 A: 17-23.

19. Hegab SA, Hanke W. Electrolyte changes, cell volume regulation and hormonal influences during acclimation of rainbow trout (Salmo gairdneri) to salt water. Comp Biochem Physiol 1986; 83A: 47-52.

20. Vislie T. Hyper-osmotic cell volume regulation in vivo and in vitro in flounder (Platichthys flesus) heart ventricles. J Comp Physiol 1980; 140: 185-191.

21. Martemyanov V.I., Vasiliev A.S. Regulation of volumes of the muscle, liver, and brain erythrocytes in crucian carp Carassius auratus (Cyprinidae) in response to increase in the osmotic concentration in blood plasma. J Ichthyology. 2018; 58: 563-569.

22. Anderson RJ, Chung HM, Kluge R, Schrier RW. Hyponatremia: a prospective analysis of its epidemiology and the pathogenetic role of vasopressin. Ann Intern Med 1985; 102: 164-168.

23. Ayus JC, Arieff AI. Chronic Hyponatremic encephalopathy in postmenopausal women: association of therapies with morbidity and mortality. JAMA 1999; 281: 2299-2304.

24. Liamis GL, Milionis HJ, Rizos EC et al. Mechanisms of hyponatremia in alcohol patients. Alcohol Alcoholism 2000; 35: 612-616.

25. Park YJ, Kim YC, Kim MO et al. Successful treatment in the patient with serum sodium level greater than $200 \mathrm{meq} / \mathrm{L}$. J Korean Med Sci 2000; 15: 701-703.

26. Somero GN. Protons, osmolytes, and fitness of internal milieu for protein function. Am J Physiol 1986; 251: R197-R213.

27. Lang F, Busch GL, Volkl H. The diversity of volume regulatory mechanisms. Cell Physiol Biochem 1998; 8: 1-45.

28. Strange K. Cellular volume homeostasis. Ad Physiol Education 2004; 28: $155-159$.

29. Argyropoulos C, Rondon-berrios H, Raj D S, et al. Hypertonicity: pathophysiologic concept and experimental studies. Cureus 2016; 8: e596. doi: $10.7759 /$ cureus. 596 . 
30. Haussinger $\mathbf{D}$. The role of cellular hydration in the regulation of cell function. Biochem J 1996; 313: 697-710.

31. Chamberlin ME, Strange K. Anisosmotic cell volume regulation: a comparative view. Am J Physiol 1989; 257: C159-C173.

32. Haussinger D, Lang F, Gerok W. Regulation of cell function by the cellular hydration state. Am J Physiol 1994; 267: E343-E355.

33. Hegab SA, Hanke W. The significance of the amino acids during osmotic adjustment in teleost fish-II. Changes in the stenohaline Cyprinus carpio. Comp Biochem Physiol 1983; 74A: 537-543.

34. Gordon MS. Intracellular osmoregulation in skeletal muscle during salinity adaptation in two species of toads. Biol Bull 1965; 128: 218-229.

35. Venkatachari SAT. Effect of salinity adaptation on nitrogen metabolism in the freshwater fish Tilapia mossambica. I. Tissue protein and amino acid levels. Marine Biol 1974; 24: 57-63.

36. Lasserre P, Gilles R. Modification of the amino acid pool in the parietal muscle of two euryhaline teleosts during osmotic adjustment. Experientia 1971; 27: 1434-1435.

37. Vislie T, Fugelli K. Cell volume regulation in flounder (Platichthys flesus) heart muscle accompanying an alteration in plasma osmolality. Comp Biochem Physiol 1975; 52A: 415-418.

38. Dunham PB. The adaptation of Tetrahymena to a high $\mathrm{NaCl}$ environment. Biol Bull 1964; 126: 373-390.

39. Maceina MJ, Shireman JV. Grass carp: effects of salinity on survival, weight loss, and muscle tissue water content. Progressive Fish-Culturist 1979; 41: 69-73.

40. Chouchane S, Fehri H, Chouchane $\mathbf{C}$ et al. Hypernatremic dehydration in children: retrospective study of 105 cases. Arch Pediatr 2005; 12: $1697-1702$.

41. Molaschi M, Ponzetto M, Massaia M et al. Hypernatremic dehydration in the elderly on admission to hospital. J Nutr Health Aging 1997; 1: $156-160$.
42. Blinks JR. Influence of osmotic strength on cross-section and volume of isolated single muscle fibres. J Physiol 1965; 177: 42-57.

43. Leader JP, Bedford JJ. Volume regulation in vitro of muscle fibres of the crab, Hemigrapsus edwardsi. J Comp Physiol 1978; 128 : $153-159$.

44. Wehner F, Sauer H, Kinne RKH. Hypertonic stress increases the Na conductance of rat hepatocytes in primary culture. J Gen Physiol 1995; 105: 507-535.

45. Weaver YR, Kiessling K, Cossins AR. Responses of the $\mathrm{Na}^{+} / \mathrm{H}^{+}$exchanger of European flounder red blood cells to hypertonic, $\beta$-adrenergic and acidotic stimuli. J Exp Biol 1999; 202: 21-32.

46. Brauner CJ, Wang T, Jensen FB. Influence of hyperosmotic shrinkage and beta-adrenergic stimulation on red blood cell volume regulation and oxygen binding properties in rainbow trout and carp. J Comp Physiol B. $2002 ; 172: 251-262$.

47. Tse WKF, Au DWT, Wong CKC. Effect of osmotic shrinkage and hormones on the expression of $\mathrm{Na}^{+} / \mathrm{H}^{+}$exchanger $-1, \mathrm{Na}^{+}-\mathrm{K}^{+}-2 \mathrm{Cl}^{-}$cotransporter and $\mathrm{Na}^{+} / \mathrm{K}^{+}$-ATPase in gill pavement cells of freshwater adapted Japanese eel, Anguilla japonica. J Exp Biol 2007; 210: 2113-2120.

48. Freire CA, Souza-Bastos LR, Amado EM, Prodocimo V, Souza MM. Regulation of muscle hydration upon hypo- or hyper-osmotic shocks: differences related to invasion of the freshwater habitat by decapod crustaceans. J Exp Zool A Ecol Genet Physiol. 2013; 319: 297-309.

49. Lang F, Busch GL, Ritter $M$ et al. Functional significance of cell volume regulatory mechanisms. Physiol reviews 1998; 78: 247-306.

50. Lang F. Mechanisms and significance of cell volume regulation. J Amer Coll Nutrition 2007; 26: 613S-623S.

51. Hoffmann EK, Lambert IH, Pedersen SF. Physiology of cell volume regulation in vertebrates. Physiol Rev 2009; 89: 193-277.

Received September 12, 2018. Accepted October 15, 2018. 